\title{
Intermodal Terminal Localisation Using a Linear Programming Approach: The Case Study of Togo and West African Landlocked Countries
}

\author{
Bomboma Kalgora \\ School of Economics and Management, Shanghai Maritime University, Shanghai, China \\ Email: research.kb@outlook.com
}

How to cite this paper: Kalgora, B. (2019) Intermodal Terminal Localisation Using a Linear Programming Approach: The Case Study of Togo and West African Landlocked Countries. Journal of Transportation Technologies, 9, 215-231.

https://doi.org/10.4236/jtts.2019.92014

Received: March 18, 2019

Accepted: April 14, 2019

Published: April 17, 2019

Copyright () 2019 by author(s) and Scientific Research Publishing Inc. This work is licensed under the Creative Commons Attribution International License (CC BY 4.0).

http://creativecommons.org/licenses/by/4.0/

\begin{abstract}
In this paper, four potential cities to host an intermodal terminal for containers flowing through the Togolese transport corridor are examined. The transport cost minimization through the corridor is the main objective. Consequently, the transport modes that offer the least cost to the transport supply chain are proposed. To attain this goal the paper aims to identify the optimal location for an intermodal terminal on the Togolese corridor, by using the mathematical linear programming model. For this, three transport scenarios are analyzed, the rail, the road, and the combination of these two transport modes to each of the landlocked countries (LLCs) capital cities of Burkina Faso, Mali and Niger. Data of the average transport cost per mode, the cargo demand of the LLCs, and the distances from origin to destinations are input in the LINGO software. Based on the optimization results, we find that among the preselected terminals, the city of Mango located at $550 \mathrm{~km}$ in the northern part of the country is the optimal host location for an intermodal terminal along the Togolese corridor. The results of this study may be helpful to transport policy makers in the quest of rendering better servicing to the landlocked countries.
\end{abstract}

\section{Keywords}

Transport, Optimization, Intermodal Transport, Terminal, Landlocked Country, Mathematical Linear Programming, Lingo

\section{Introduction}

In today's ever increasing demand-driven world, transport supply chain has become one of the crucial focus areas in many businesses. It is easy to underestimate the complexity of global supply chain. Yet the growth of global market, the 
increasing customer expectations, the raising costs, the more intense and diverse competitive pressures are driving the development of new transport strategies to cope with the intricate demand of cargo transport. Over the last 20 years or so, the growth of intra-continental trade and the observed increase of road transport inefficiencies have led to the need of examining the issue of competition with alternative modes (Snaddon D. R., 2001) [1]. Transport policies at different levels advocate rail as being a more sustainable traffic mode and therefore propose a shift of volumes from road to more energy efficient traffic modes. In this regard, Parola F., \& Sciomachen A. (2005) [2] imply that the only strategic decision would be the implementation of rail for connecting seaports with hinterland through inland intermodal terminals. Those terminals are of major importance for the efficiency of the intermodal transport as well as for efficient access from/to seaports. Seaports and inland intermodal terminals are connected with high capacity traffic modes, such as rail, rather than only with road. According to Jean-Paul R. (2017) [3], the selection of a transportation mode is the outcome of a number of factors. The author mentioned factors among which the cost being an important element to take into account, but also service, frequency and the general value of time attributed to the goods being transported. The attractiveness of a specific mode in relation to others is hence a trade-off between cost and value of time.

Though the causality between transport and wealth generation is not specific in the literature, transportation developments that have taken place since the beginning of the industrial revolution have been linked to growing economic opportunities. The role of infrastructure and reliable efficient transport in ensuring the movement of people and goods is obviously central for the development of countries. At each stage of societal development, a particular transport technology has been developed or adapted with an array of impacts. There has been significant growth in research on modal transport in freight distribution since the 1990s (Anny-del-Mar A.-A. \& José M.-F., 2017) [4]. Improving transportation and especially intermodal transport has become a major goal in modern transport policy. In order to enhance logistics efficiencies and boost international trade in Africa, since the mid-1990s governments have embarked on formulating strategic reforms, particularly in the ports and inland transportation, in collaboration with lending organizations like the World Bank and African Development Bank (UNCTAD, 2003) [5].

The transport logistics accounts for as much as $30 \%$ of the total cost of logistics operations, and is by far the largest component of the cost structure of a business' logistics (Chang Y.H., 1998) [6]. The inland transportation, happens to cost more in developing countries than in developed ones. These countries show a significant cost gap when compared to OECD countries. A poor transport service level can negatively affect the competitiveness of regions and corporations and thus have a negative impact on the regional added value and employment. The lack of transport infrastructures can be seen as a constraining factor on development. Although transport by itself is not a sufficient condition for devel- 
opment, in developing economies, the lack of transportation infrastructures and regulatory impediments are jointly impacting economic development by not only conferring higher transport costs, but also delaying rendering supply chain management to make them unreliable (Jean-Paul R., 2017) [3]. For these reasons, the overall cost of transportation and, by extension, doing business in African countries is much higher than in other developing regions like Latin America and Asia (Amjadi A., \& Yates A., 1995) [7].

In fact, in view of the crucial role transport supply chain plays, the need to reduce inland logistics costs is more acute in developing countries. To this end, Limão N., \& Venables A. J. (2001) [8] conclude that the high costs of transportation in Sub-Sahara Africa accounts for much of the region's poor economic performance. They report that a landlocked country's transport costs can be up to 55 percent higher than those of a comparable coastal country.

To cope with the ever growing demand for cargo transport and consequently the increasing containership size (Kalgora B. \& Christian T.M., 2016) [9], many developed countries have attained substantial transport costs cut on their inland haulage by implementation of optimized transportation in the transport supply chain. This transport optimization mainly consisted on the introduction of transport intermodality, thus attaining substantial economies of scale in the inland transport main haulage. In line with this evolution, and this ever increasing trade volume, developing regions in the world such as the West Africa transport system have been of recent topic on how to minimize the inland transport cost henceforth from coastal to landlocked countries.

However, a research investigating the intermodal transport and the intermodal terminal localization in Sub-Saharan Africa, especially for West Africa countries which have seaports and are servicing the landlocked countries of Burkina Faso, Mali and Niger has not been found in the literature. Therefore the study attempt to determine the optimal intermodal terminal for cargo transport flowing through the Togolese corridor to and from the hinterland mentioned countries, using the mathematical linear programming function computed in the LINGO software. The remainder of this study is organized in following way. Section 2 discusses the literature review pertaining of the intermodal terminal and intermodal transport. Section 3 presents the data and the network modelling of the intermodal transport. Section 4 elaborates the mathematical objective function of the intermodal terminal localization, while Section 5 presents the obtained results. Then the study concludes in Section 6 with a suggestion approach toward policy makers.

\section{Literature Review}

\subsection{Intermodal Terminal and Transport Definition in the Literature}

Several authors came up with various definition of the intermodal terminal. As the interface point between rail and road, they are critical elements in the total 
freight distribution chain (Luis F., \& Julius S., 1995) [10]. Bart W.W., et al., (2007) [11] and the UNCTAD (2004) [12], also identified terminals as nodes, interchange or articulation points, where different transport links meet. They serve as consolidation nodes in intermodal transportation network where containers are transferred between freight trains and trucks (Peng G., et al., 2018) [13]. The role of intermodal terminal has also increased significantly through the implementation of intermodal technologies and, over time, terminals have become increasingly technically and technologically complex systems. Consequently, the European Conference of Ministers of Transport (1993) [14] and Macharis C, \& Bontekoning Y.M. (2004) [15] define intermodal freight transport as the combination of at least two modes of transport in a single transport chain, without a change of container for the goods, with most of the route travelled by rail, inland waterway or ocean-going vessel and with the shortest possible initial and final journeys by road. Transportation costs constitute a significant portion of total transport supply chain spending (Fredrik Bärthel \& Johan, 2004) [16], henceforth intermodal freight transport works best within markets with relatively large flows occurring over long distances with the aim of reducing the costs. It depends on four major factors: location, efficiency, financial sustainability and rail level of service (Meyrick \& Associates, 2006) [17], of which the terminal localization is one of the most crucial factors.

\subsection{The Intermodal Terminal Localization Approach in the Literature}

Most terminal location research has focused primarily on problems in which each demand point is uniquely allocated to a single terminal, meaning that, each demand point can send and receive via only a single terminal (Limbourg S., \& Jourquin B., 2008) [18]. A large part of models dealt with the problem of designing intermodal terminals, including the planning for their location. Even with regard to the problem of optimizing the location, there are many different models using different methods (Mayer G., \& Wagner B., 2002) [19]. Early researchers on the topic have addressed continuous (planar) and discrete terminal location problems from a location theory perspective. Likewise, O'Kelly M.E. (1986) [20] presented a Weiszfeld type solution procedure for continuous terminal location with one and two terminals. Others continuous hub location research have considered a single hub minimax problem (O'Kelly M.E., \& Harvey J.M., 1991) [21], planar and spherical problems (Aykin T., \& Brown G.F., 1992) [22] and problems with squared Euclidean distances (O'Kelly M.E., 1992) [23]. Moreover, Klincewicz J.G. (1991) [24] has considered several exchange heuristics, and has shown promising results using Tabu search and GRAP (greedy randomized adaptive search procedure) heuristics for single allocation intermodal location problems (Klincewicz J.G., 1992) [25]. Skorin-Kapov D. \& Skorin-Kapov J. (1994) [26] analyze a more comprehensive Tabu search heuristic and O'Kelly, M.E. et al. (1995) [27] developed lower bounds for hub location problems. Weber's theory of location is an example of lowest costs optimization 
based on minimizing transport cost.

Koen H. van Dam, et al. (2007) [28], in their paper develop an integral model for the evaluation of road-rail intermodal freight hub location decisions. The authors' research focuses on road-rail intermodal transport which is contestable with road only options over longer distances. Their research results showed that the transport by train is cost-effective for transportation over a long distance and with large quantities while road is more flexible in its route and accessibility for collection and distribution activities for medium to short distances. Also Pekin E., \& Macharis C. (2007) [29] used a GIS based location analysis model for intermodal terminals, while Kayikci Y. (2010) [30] applies a fuzzy AHP and artificial neural networks methods in the process of decision-making to select the most appropriate location for an intermodal freight centre. Bogusz W., et al. (2016) [31], proposed the location of intermodal terminals including port, regional, local and transit terminals. Their work also gave the forecast of intermodal units' transshipments by the year 2030. They also proposed organizational solutions that provide for significant improvement to the quality of intermodal transport. In the case of rail-road transport terminals, their work suggested that, services should cover up to $150 \mathrm{~km}$ using the road transport means. From a practical point of view, one should select a location in such place that the area of operation of all the terminal covers the largest possible area of the country.

Other research in the field used linear programming for a set of estimated potential locations as input for an iterative procedure based on the p-hub median problem (Limbourg S., \& Jourquin B., 2008) [18]. Their paper focused on hub location in systems involving transportation of passengers or goods. They concluded that the performance of the optimal configuration that results from their model (for the same number of hubs) is more than three times better in terms of reduction of the ton. $\mathrm{km} /$ year transported by road. This solution would achieve $35 \%$ of the Marco Polo I annual programme objective which aims at achieving a traffic shift or avoidance. This is a substantial part of the expected yearly aggregate increase in international road freight traffic, measured in tonne-kilometres, to modes of transport with lower external costs in which road journeys are as short as possible Marco Polo II (2013) [32]. A shift from the road to more environmentally friendly modes, introduced by the European Commission (2001) White Paper [33]. Arnold P., et al. (2004) [34] used simulated annealing to find near-optimal locations of terminals. The resulting linear integer program was solved heuristically. The model was illustrated for the location of rail/road terminals in the Iberian Peninsula. In this application, the impact of variations in the supply of transport on modal shares of containerized freight transport was explored.

Generally, throughout the literature pertaining to this field of research, few studies used the linear programming for the intermodal terminal localization. Furthermore, there is no trace of previous pieces of literature on the topic of intermodal terminal localization for Togo, to a larger sense in West Africa. 


\subsection{The Methodological Approach of an Intermodal Terminal Localization}

The process begins with an analysis of potential location sites. A new freight hub has to be economically viable so a certain transport volume has to be reached with a good price for transport and handling to ensure the new intermodal freight terminal is a beneficial investment. The development of the hinterland intermodal terminal requires innovative solutions so as to shift the freight to the railway, good railway services and the introduction of block trains (Jencek P., \& Twrdy E., 2008) [35]. For the development of intermodal transport a sufficiently large concentration of freight is needed in one place.

The platforms should be set up and implemented in accordance with the regional demands and taking into consideration all of the important influential factors and their mutual interactions. For this, the following need to be performed:

- calculating the potential terminal throughput,

- defining the optimal type of platform,

- defining the optimal location,

- integrating the existent non-connected platforms into the functional network,

- calculating the transportation effect of the platforms,

- analysing the transportation effects,

- determining environmental effects,

- determining the possibilities for operation and further development of platforms.

The analysis of the regional needs for a freight platform is of utmost importance and represents the basis for reaching all subsequent decisions. The volume of freight handled that can be realistically expected at an individual terminal is very important for the development of the regional terminal. This depends on the function developed by the terminal, the terminal catchment area and of course on the attractiveness of the individual location. Jencek P., \& Twrdy E. (2008) [35] gave recommendations concerning the volume-TEU (Twenty-foot equivalent unit) - throughput (see Table 1). They suggest in terms of tonnage, that the minimum freight flows in the terminal catchment area should be 4 million tons/year. This would enable the formation of 1 block train daily and would justify the development of an intermodal terminal.

\section{Data and Modelling}

\subsection{Data}

Table 2 shows the import and export freight demand from 2005 to 2016 summed up for each destination. The data was obtained from the Burkinabe, Mali and Niger's Chamber of Commerce and PMAWCA (2016) [36].

The research forecast the cargo volume flow for the next 10 years (from 2017 to 2026). To attain this forecast, the researcher proceed by simply calculating the 
rate of evolution by variation period of $n$ and then the overall average evolution rate which are both mathematically presented as followed:

Calculation of Rate Evolution by variation of year,

$$
T_{m}=\frac{t_{G 1}+t_{G 2}+\cdots+t_{G n}}{n}
$$

$t_{G}$ : Rate of evolution by variation period of $(n)$.

$V_{i}$ : Initial volume of year $(n)$.

$V_{j}$ : Final volume of year $(n+1)$.

Calculation of Overall Average Evolution Rate,

$$
T_{m}=\frac{t_{G 1}+t_{G 2}+\cdots+t_{G n}}{n}
$$

$T_{m}$ : Overall Average Evolution Rate.

$t_{G 1}$ Rate of evolution by variation period from $(n)$ to $(n+1)$.

$t_{G n}$ Rate of evolution by variation period over $(n)$ period.

$n$ : number of variation period.

Evolution Rate of demand obtained is on average 10.9 percent on yearly basis. This result meets our expectations as the world organization of road transport (IRU) ${ }^{1}$ mentioned it in their report of fact sheet typical problems of intermodal terminals, that some terminals have an average growth rate of up to $10 \%$ on yearly basis. From these mathematical calculations, we obtain the results presented in Table 3 of which the forecasted volume starts from the year 2017. Because of the spatial constraints and the challenges of extension of the terminal in the future, the storage space may become a limiting factor. Therefore this study is using the forecasted demand of the year 2023 as a benchmark. The year 2023 is selected as the benchmark year based on the Togolese PND (Plan National de Developpement) for the period 2018-2022. The PND is a national development plan which aims at the structural transformation of the Togolese economy. Its first three effects of the expected impacts in ax 1 of the plan document focus on the transport sector (Nadoun C., 2019) [37]. The forecasted imports and exports demand is used to determine the optimal intermodal terminal location along the Lomé-Ouagadougou, Niamey and Bamako transport corridors routes.

Table 1. Intermodal terminal throughput limit recommendation.

\begin{tabular}{cc} 
Terminal Size & Terminal Throughput Limit \\
Small terminals & 5000 TEU/year \\
Medium terminals & 5000 to 20,000 TEU/year \\
Large terminals & 20,000 to 40,000 TEU/year \\
Super large terminals & more than 40,000 TEU/year \\
\hline
\end{tabular}

Source: Adapted from Jencek P., \& Twrdy E. (2008).

${ }^{1}$ Union Internationale des Transports Routiers, https://www.iru.org. 
Table 2. Demand imports \& exports data for selected LLCs in W/A (million tons).

\begin{tabular}{cccccccccccccc}
\hline & \multicolumn{10}{c}{ Year } \\
\cline { 2 - 5 } & 2006 & 2007 & 2008 & 2009 & 2010 & 2011 & 2012 & 2013 & 2014 & 2015 & 2016 \\
\hline $\begin{array}{c}\text { Burkina Faso } \\
\text { (Ouagadougou) }\end{array}$ & 1.87 & 2.26 & 2.6 & 2.28 & 3.31 & 4.76 & 5.52 & 5.99 & 5.77 & 6.33 & 7.02 \\
Mali (Bamako) & 3.9 & 4.54 & 4.82 & 3.78 & 4.76 & 5.11 & 5.89 & 5.99 & 6.06 & 6.46 & 7.16 \\
Niger (Niamey) & 1.58 & 1.78 & 2.26 & 2.79 & 3.11 & 3.46 & 3.34 & 3.6 & 3.94 & 5.21 & 5.79 \\
Total & 7.35 & 8.58 & 9.68 & 8.85 & 11.18 & 13.33 & 14.75 & 15.58 & 15.77 & 18 & 19.97 \\
\hline
\end{tabular}

Source: Burkinabe, Mali and Niger's Chamber of Commerce and PMAWCA.

Table 3. Forecasted demand imports \& exports data for selected LLCs in W/A (millions of tons).

\begin{tabular}{ccccccc|c|ccc}
\hline & \multicolumn{10}{c}{ Year } \\
\cline { 2 - 9 } LLC & 2017 & 2018 & 2019 & 2020 & 2021 & 2022 & 2023 & 2024 & 2025 & 2026 \\
\hline $\begin{array}{c}\text { Burkina Faso } \\
\text { (Ouagadougou) }\end{array}$ & 7.79 & 8.64 & 9.58 & 10.62 & 11.78 & 13.07 & 14.49 & 16.07 & 17.83 & 19.77 \\
Mali (Bamako) & 7.94 & 8.81 & 9.77 & 10.83 & 12.02 & 13.33 & 14.78 & 16.39 & 18.18 & 20.16 \\
Niger (Niamey) & 6.42 & 7.12 & 7.90 & 8.76 & 9.72 & 10.78 & 11.95 & 13.26 & 14.70 & 16.31 \\
Total & 22.15 & 24.56 & 27.24 & 30.22 & 33.51 & 37.17 & 41.22 & 45.72 & 50.71 & 56.24 \\
\hline
\end{tabular}

Source: Processed by the Author.

Consequently, the proposed optimization model takes into account five types of parameters: the spatial parameter compiled in Table 3 (cargo's demand from the LLCs), the transport mode (rail and road), the preselected intermodal terminals and the distance between nodes (see Appendix $1 \&$ \&). The average transport cost is in USD per ton per kilometre. This average transport price mechanism is calculated based on the fuel cost, road conditions, as well as any indirect and direct costs associated with inland transportation (Borderless, 2016) [38]. The upper limit on the freight rates is fixed by the road freight rates; i.e. the railway cannot set the freight rates higher than the road freight rates unless customers are willing to pay more than the road freight rates. Rajiv D., et al. (2011) [39] suggest that the freight rate should be set in sort to determine the optimum pricing policy and terminal location in order to guarantee a certain level of profit for the railway from the intermodal service; i.e. pricing should be set in such a way that the railway can achieve this profit without losing traffic to road transport. Henceforth this study applies the freight rate of $0.14 \mathrm{USD} / \mathrm{ton} / \mathrm{km}$ as same as the one from Ivory Coast, added to the fact that the two countries share numerous similarities.

\subsection{Intermodal Transport Modeling}

It is then necessary to determine the location of the terminal to open as well as the path of the cargo streams so as to minimize the total transport cost. 
We designate by:

OD: all the cargo from origin to destination,

O: the origin (international gateway),

D: all destinations (3 LLCs),

$\mathrm{T}$ : all the preselected terminals.

Figure 1 illustrates the representation of the intermodal transport. The mathematical optimization model is formulated as an integer linear programming problem with the minimization of transport costs as objective function (Schrijver A., 1998) [40].

\section{Intermodal Terminal Location Objective Function}

The decision to open a terminal or not can be represented by a binary variable $y_{i}$ which will be worth 1 if the terminal must be open and 0 otherwise. Similarly, the cargo stream $X$ from an origin $o$ to a terminal $i$, by type of transport mode $r$, on the one hand, and a terminal $i$ to a destination $j$ and by type of transport mode $r$ will be represented by variables of streams $X_{o i r}^{p}$ and $X_{i j r}^{p}$. The average transport cost $C$ of $p$ from the origin o to the terminal $i$ and by type of transport mode $r$, on the one hand and secondly from a terminal $i$ to a destination $j$ per type of transport mode $r$ is represented by transport cost variables $C_{\text {oir }}^{p}$ and $C_{i j r}^{p}$ On one hand the distance ( $d$ ) separates the transport point of $(p)$ from the origin ( $o$ ) to a terminal $(i)$ and by type of transport mode $(r)$, and yet on the other hand, the transport distance of $(p)$ from a terminal $(i)$ to a destination $(j)$ and by type of transport mode $(r)$ is appropriate. It is represented by $d_{o i r}^{p}$ and $d_{i j r}^{p}$. The model derived from all these notations is the following:

$$
\min =\sum_{o} \sum_{i} \sum_{r} C_{o i r}^{p} d_{o i r}^{p} X_{o i r}^{p}+\sum_{i} \sum_{j} \sum_{r} C_{i j r}^{p} d_{i j r}^{p} X_{i j r}^{p}
$$

Constraints:

$$
\begin{gathered}
X_{o i r}^{p} \leq y_{i} M \\
X_{i j r}^{p} \leq y_{i} M \\
\sum_{i} y_{i}=1 \\
\sum_{i} \sum_{f} X_{i j r}^{p}=a_{i} \\
X_{o i r}^{p} \geq 0 ; X_{i j r}^{p} \geq 0 \\
y_{i}=\{0,1\}
\end{gathered}
$$

Set:

$r=\{1,2\} \quad$ Transport modes

$i=\{1,2,3,4\} \quad$ Preselected terminals

$j=\{1,2,3\} \quad$ Destinations

M Express infinity

$a_{i} \quad$ Express destination cargo volume demand 

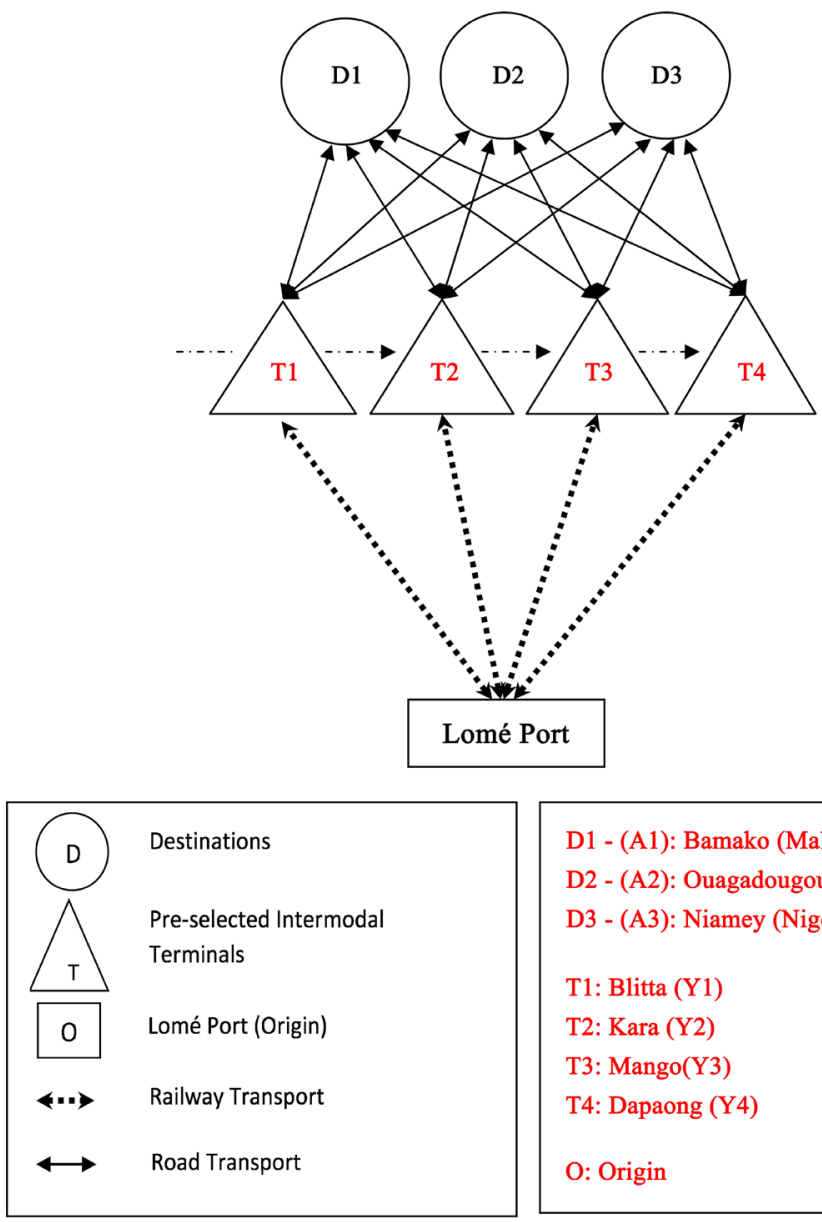
D1 - (A1): Bamako (Mali)
D2 - (A2): Ouagadougou (Burkina Faso)
D3 - (A3): Niamey (Niger)
T1: Blitta (Y1)
T2: Kara (Y2)
T3: Mango(Y3)
T4: Dapaong (Y4)
O: Origin

Figure 1. Intermodal transport layout. Source: Processed by the Author.

The objective function of the model contains the average cost of transportation USD $\$ /$ ton $/ \mathrm{km}$ and by mode of transport, the origin distance hub and mode of transport passing through an intermodal terminal and the volume of cargo transported from origin to destination all also passing through an intermodal terminal. The model was implemented in "LINGO" by LINDO Systems ${ }^{2}$. Designed to model and solve linear, nonlinear, quadratic, integer and stochastic optimization problems. Table 4 presents the basic elements of mathematical modelling language syntax of "LINGO".

Optimization occurs after the implementation of the model in the LINGO mathematical modelling language (Figure 2). Optimization results are shown in Table 5. The optimization process involves finding the global solution for the specific data, which in this case means the best location for the intermodal terminal in terms of lowering transport costs to satisfy LLCs transport needs through the corridor.

\section{The Intermodal Terminal Localization Results}

The optimization results are shown in Table 5. The most optimal location for ${ }^{2}$ https://www.lindo.com. 
the intermodal terminal is $Y_{3}$ which represents the city of Mango is located at $550 \mathrm{~km}$ away from the Lomé Port, in the northern part of Togo.

Table 4. The basic syntax of "LINGO" mathematical modelling language.

\begin{tabular}{cc}
\hline Mathematical nomenclature & LINGO syntax \\
\hline Minimum & MIN $=$ \\
$\sum Z_{o j r}$ & $@ \operatorname{sum}(\operatorname{ORDER}(\mathrm{o}, \mathrm{j}, \mathrm{r}))$ \\
$\mathrm{j}=1$. M for each destination $(\mathrm{j})$ & @for(DESTINATION $(\mathrm{j}))$ \\
in the set of destinations & $*$ \\
$\bullet$ & $=$ \\
$Y \in\{0,1\}$ & $@ b$ bin $(\mathrm{y})$
\end{tabular}

Table 5. Terminal location optimized results.

\begin{tabular}{|c|c|c|c|}
\hline \multicolumn{4}{|c|}{ Global optimal solution found. } \\
\hline Objective value: & & $0.2149185 \mathrm{E}+11$ & \\
\hline Objective bound: & & $0.2149185 \mathrm{E}+11$ & \\
\hline Infeasibilities: & & $0.1862645 \mathrm{E}-08$ & \\
\hline Extended solver steps: & & 2 & \\
\hline \multirow[t]{26}{*}{ Total solver iterations: } & & 12 & \\
\hline & Variable & Value & Reduced Cost \\
\hline & M & 9999999. & 0.000000 \\
\hline & $\mathrm{Y}(1)$ & 0.000000 & 0.000000 \\
\hline & $\mathrm{Y}(2)$ & 0.000000 & $-0.8839999 \mathrm{E}+10$ \\
\hline & $\mathrm{Y}(3)$ & 1.000000 & 0.000000 \\
\hline & $\mathrm{Y}(4)$ & 0.000000 & $-0.7139999 \mathrm{E}+10$ \\
\hline & $\mathrm{A}(1)$ & $0.1449104 \mathrm{E}+08$ & 0.000000 \\
\hline & $A(2)$ & $0.1478004 \mathrm{E}+08$ & 0.000000 \\
\hline & $\mathrm{A}(3)$ & $0.1195201 \mathrm{E}+08$ & 0.000000 \\
\hline & $\mathrm{X} 1(1,1,1)$ & 0.000000 & 263.0000 \\
\hline & $\mathrm{X} 1(1,1,2)$ & 0.000000 & 263.0000 \\
\hline & $\mathrm{X} 1(1,2,1)$ & 0.000000 & 411.0000 \\
\hline & $\mathrm{X} 1(1,2,2)$ & 0.000000 & 411.0000 \\
\hline & $\mathrm{X} 1(1,3,1)$ & 0.000000 & 550.0000 \\
\hline & $\mathrm{X} 1(1,3,2)$ & 0.000000 & 550.0000 \\
\hline & $\mathrm{X} 1(1,4,1)$ & 0.000000 & 620.0000 \\
\hline & $\mathrm{X} 1(1,4,2)$ & 0.000000 & 620.0000 \\
\hline & $\mathrm{X} 2(1,1,1)$ & 0.000000 & 1332.000 \\
\hline & $\mathrm{X} 2(1,1,2)$ & 0.000000 & 1332.000 \\
\hline & $\mathrm{X} 2(1,2,1)$ & 0.000000 & 1254.000 \\
\hline & $\mathrm{X} 2(1,2,2)$ & 0.000000 & 1254.000 \\
\hline & $\mathrm{X} 2(1,3,1)$ & 0.000000 & 464.0000 \\
\hline & $\mathrm{X} 2(1,3,2)$ & 0.000000 & 464.0000 \\
\hline & $\mathrm{X} 2(2,1,1)$ & 0.000000 & 975.0000 \\
\hline & $\mathrm{X} 2(2,1,2)$ & 0.000000 & 975.0000 \\
\hline
\end{tabular}




\section{Continued}

\begin{tabular}{lll}
\hline $\mathrm{X} 2(2,2,1)$ & 0.000000 & 357.0000 \\
$\mathrm{X} 2(2,2,2)$ & 0.000000 & 357.0000 \\
$\mathrm{X} 2(2,3,1)$ & 0.000000 & 0.000000 \\
$\mathrm{X} 2(2,3,2)$ & 0.000000 & 0.000000 \\
$\mathrm{X} 2(3,1,1)$ & 9999999. & 0.000000 \\
$\mathrm{X} 2(3,1,2)$ & 4491043. & 0.000000 \\
$\mathrm{X} 2(3,2,1)$ & 9999999. & 0.000000 \\
$\mathrm{X} 2(3,2,2)$ & 4780038. & 0.000000 \\
$\mathrm{X} 2(3,3,1)$ & 9999999. & 0.000000 \\
$\mathrm{X} 2(3,3,2)$ & 1952014. & 0.000000 \\
$\mathrm{X} 2(4,1,1)$ & 0.000000 & 433.0000 \\
$\mathrm{X} 2(4,1,2)$ & 0.000000 & 433.0000 \\
$\mathrm{X} 2(4,2,1)$ & 0.000000 & 364.0000 \\
$\mathrm{X} 2(4,2,2)$ & 0.000000 & 364.0000 \\
$\mathrm{X} 2(4,3,1)$ & 0.000000 & 0.000000 \\
$\mathrm{X} 2(4,3,2)$ & 0.000000 & 0.000000 \\
\hline
\end{tabular}

Source: LINGO Solver Results.

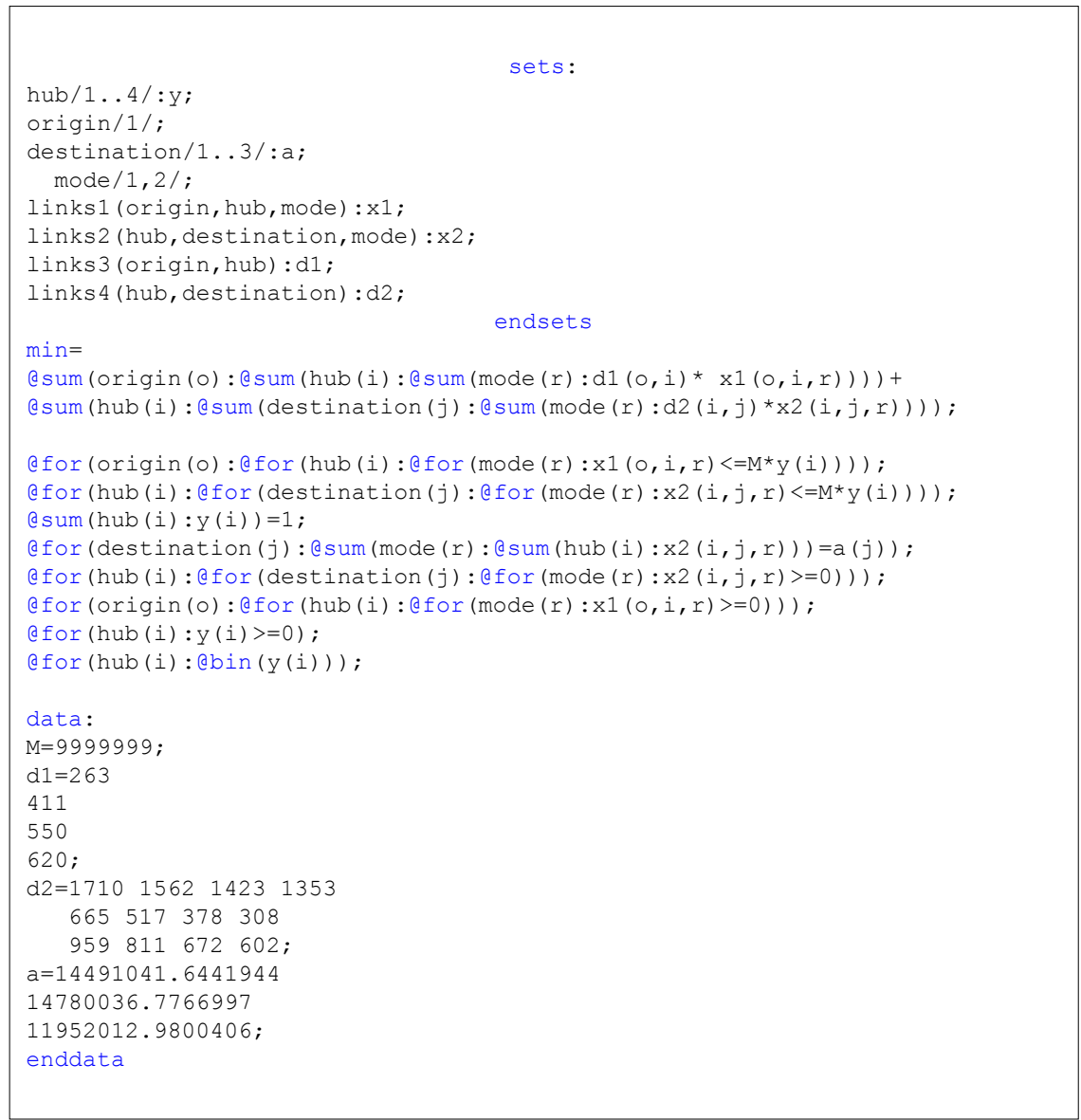

Figure 2. Part of the file scm.lng (Transport supply chain cost optimization model in LINGO). Source: Processed by the Author. 
Figure 3, is a geographical illustration of the intermodal terminal location on the Togolese corridor with the city of Mango encircled in red.

Based on computational experiments, results, analysis, the research can state that the proposed model and its implementation ensure a very large range of application. First, to determine the best location for intermodal terminal along the corridor which offers an adequate solution for decision support in transport supply chain management. Second, minimize the inland total transport cost through the corridor, thus satisfying the needs of customers, and this based on the determination of the optimal location for the intermodal terminal.

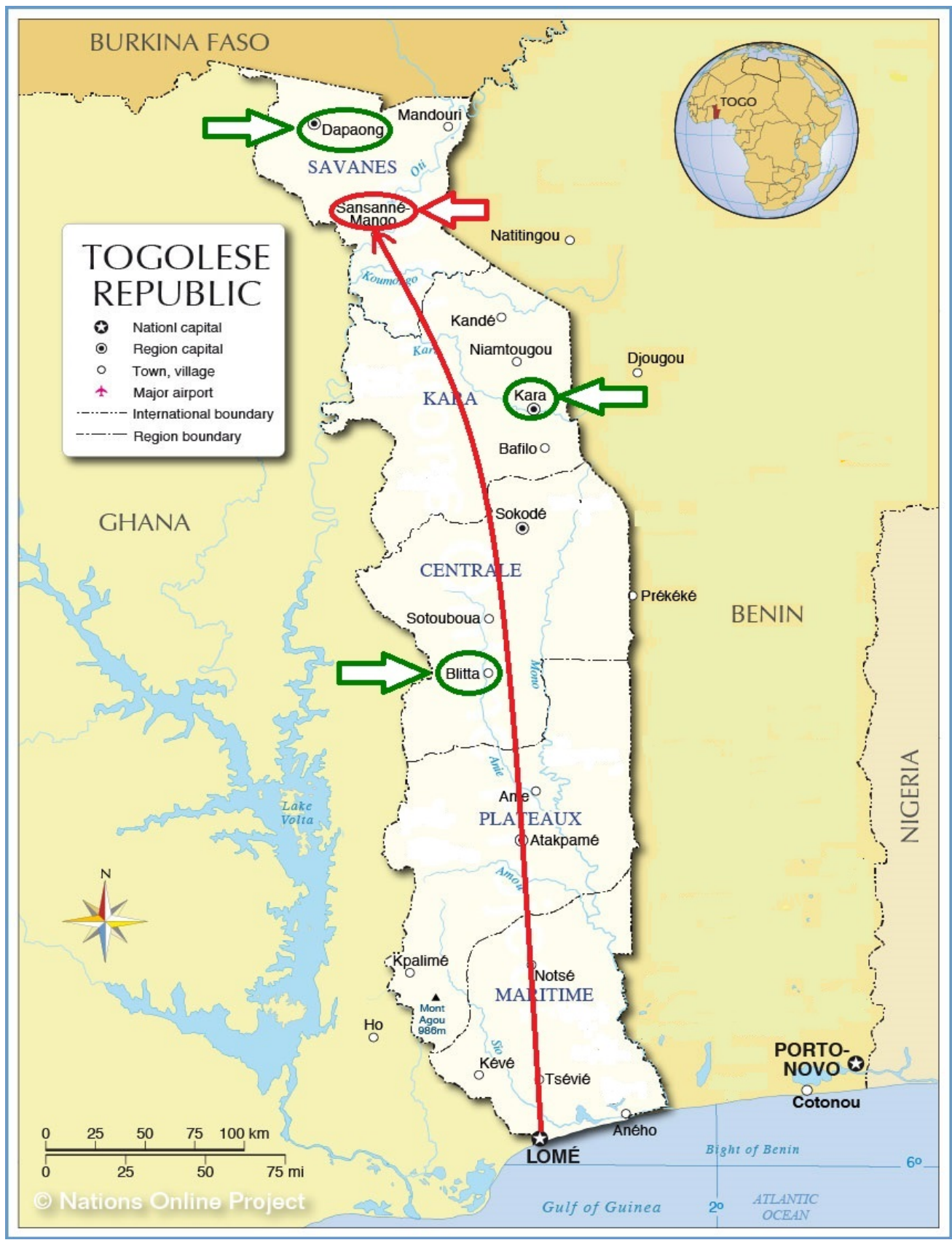

Figure 3. Map of Togo with optimal intermodal terminal. Source: Processed by the Author. 


\section{Conclusions}

The choice of location for an intermodal transport terminal is an important component in a regional transport supply chain system and a paramount decision for investors. It is of crucial importance in the logistic industry and research on the topic revealed that it deserves particular attention from practitioners. The reason lies in the fact that assessing the construction resources, time, and cost involved. If decision is made to build a logistic intermodal terminal at a specific location, but there is something faulty in the decision-making process, henceforth there is no question of destroying it within a few days after finding.

The paper developed the intermodal terminal network framework for the case study of the intermodal transport through the Togolese corridor. The present framework consisted of determining the optimal intermodal terminal location using the mathematical linear programming model computed in the LINGO software. This involved the modelling of the transport network, while taking into account the demand forecast of year 2023 of the 3 LLCs. This demand forecast was required to determine the viability of such a project. This research adds value to the transport sector in Togo and is unique in the sense that it's the first of its type to identify an optimal intermodal terminal location on the Togolese corridor through the use of an optimization method of mathematical linear programming. The present research identified the city of Mango as the optimal location for the intermodal terminal. The Mango city is located $550 \mathrm{~km}$ north of Lomé (Capital city of Togo). The optimization results reveal the optimal intermodal terminal location in terms of total transport cost minimization for containers cargo in direction to 3 LLCs of Burkina Faso, Mali and Niger. In line with the findings and in regard to the increasing trade volume due to the ever growing demand for transport cargo to and from the landlocked countries of Burkina Faso, Mali and Niger, this case study highlights the merits of the intermodal transport for the Togolese transport industry and, advises policy makers to take into consideration its results.

\section{Conflicts of Interest}

The author declares no conflicts of interest regarding the publication of this paper.

\section{References}

[1] Snaddon, D.R. (2001) Competition in Transportation-A Literature Analysis. Technovation, 21, 375-383. https://doi.org/10.1016/S0166-4972(00)00053-5

[2] Parola, F. and Sciomachen, A. (2005) Intermodal Container Flows in a Port System Network: Analysis of Possible Growths via Simulation Models. International Journal of Production Economics, 97, 75-88. https://doi.org/10.1016/j.ijpe.2004.06.051

[3] Jean-Paul, R. (2017) The Geography of Transport Systems. Fourth Edition, Routledge, New York, $440 \mathrm{p}$.

[4] Anny-del-Mar, A.-A. and José, M.-F. (2017) Intermodal Transport in Freight Distribution: A Literature Review. Journal of Transport Review, 37, 782-807. 
[5] UNCTAD (2003) African Ports: Reform and the Role of the Private Sector. Secretariat of UNCTAD (UNCTAD/SDTE/TLB/5).

[6] Chang, Y.H. (1998) Logistical Management. Hwa-Tai Bookstore Ltd.

[7] Amjadi, A. and Yates, A. (1995) Have Transport Costs Contributed to the Relative Decline of African Exports? Some Preliminary Evidence. Policy Research Working Paper No. 1559, World Bank, Washington DC.

[8] Limão, N. and Venables, A.J. (2001) Infrastructure, Geographical Disadvantage, Transport Costs and Trade. The World Bank Economic Review, 15, 451-479. https://doi.org/10.1093/wber/15.3.451

[9] Kalgora, B. and Christian, T.M. (2016) The Financial and Economic Crisis, Its Impacts on the Shipping Industry, Lessons to Learn: The Container-Ships Market Analysis. Open Journal of Social Sciences, 4, 38-44. https://doi.org/10.4236/jss.2016.41005

[10] Luis, F. and Julius, S. (1995) Measuring the Performance of Intermodal Freight Terminals. Journal Transportation Planning and Technology, 17, 269-280. https://doi.org/10.1080/03081069308717517

[11] Bart, W.W., Enno, M. and Peter, N. (2007) Intermodal Freight Terminals: An Analysis of the Terminal Market. Journal of Transportation Planning and Technology, 23, 105-128.

[12] UNCTAD (2004) Assessment of a Seaport Land Interface: An Analytical Framework. UNCTAD Secretariat, UNCTAD/SDTE/TLB/MISC/2004/3.

[13] Peng, G., Wenming, C., Yi, W. and Nils, B. (2018) Gantry Crane Scheduling in Intermodal Rail-Road Container Terminals. International Journal of Production Research, 56, 5419-5436. https://doi.org/10.1080/00207543.2018.1444812

[14] European Conference of Ministers of Transport (1993) Terminology on Combined Transport. http://www.cordis.lu/transport

[15] Macharis, C. and Bontekoning, Y.M. (2004) Opportunities for OR in Intermodal Freight Transport Research: A Review. European Journal Operation Research, 153, 400-416. https://doi.org/10.1016/S0377-2217(03)00161-9

[16] Bärthel, F. and Johan (2004) Developing Intermodal Transport for Small Flows over Short Distances. Journal of Transportation Planning and Technology, 27, 403-424.

[17] Meyrick and Associates (2006) National Intermodal Terminal Study. Australian Department of Transport and Regional Services, Publication 10781.

[18] Limbourg, S. and Jourquin, B. (2008) Optimal Rail-Road Container Terminal Locations on the European Network. Transportation Research Part E, 45, 551-563. https://doi.org/10.1016/j.tre.2008.12.003

[19] Mayer, G. and Wagner, B. (2002) Hublocator: An Exact Solution Method for the Multiple Allocation Hub Location Problems. Computers and Operations Research, 29, 715-739. https://doi.org/10.1016/S0305-0548(01)00080-6

[20] O'Kelly, M.E. (1986) The Location of Interacting Hub Facilities. Transportation Science, 20, 92-106. https://doi.org/10.1287/trsc.20.2.92

[21] O’Kelly, M.E. and Harvey, J.M. (1991) Solution Strategies for the Single Facility Minimax Hub Location Problem. The Journal of the Regional Science Association International, 70, 367-380. https://doi.org/10.1007/BF01434594

[22] Aykin, T. and Brown, G.F. (1992) Interacting New Facilities and Location-Allocation Problem. Transportation Science, 3, 212-222. https://doi.org/10.1287/trsc.26.3.212

[23] O’Kelly, M.E. (1992) A Clustering Approach to the Planar Hub Location Problem. Annals of Operations Research, 40, 339-353. https://doi.org/10.1007/BF02060486 
[24] Klincewicz, J.G. (1991) Heuristics for the p-Hub Location Problem. European Journal of Operation Research, 53, 25-37. https://doi.org/10.1016/0377-2217(91)90090-I

[25] Klincewicz, J.G. (1992) Avoiding Local Optima in the p-Hub Location Problem Using Tabu Search and GRASP. Annals of Operations Research, 40, 283-302. https://doi.org/10.1007/BF02060483

[26] Skorin-Kapov, D. and Skorin-Kapov, J. (1994) On Tabu Search for the Location of Interacting Hub Facilities, Forthcoming in European. Operational Research, 73, 502-509. https://doi.org/10.1016/0377-2217(94)90245-3

[27] O’Kelly, M.E., et al. (1995) Lower Bounds for the Hub Location Problem. Location Science, 41, 713-721. https://doi.org/10.1287/mnsc.41.4.713

[28] van Dam, K.H., Zofia, L., Luis, F. and Ackchai, S. (2007) Planning the Location of Intermodal Freight Hubs: An Agent Based Approach. IEEE International Conference on Networking, Sensing and Control, London, 15-17 April 2007, 187-192. https://doi.org/10.1109/ICNSC.2007.372774

[29] Pekin, E. and Macharis, C. (2007) A GIS-Based Location Analysis Model for Intermodal Terminals. International Logistics and Supply Chain Congress, Istanbul.

[30] Kayikci, Y. (2010) A Conceptual Model for Intermodal Freight Logistics Centre Location Decisions. The Asian Journal of Shipping and Logistics, 27, 331-335. https://doi.org/10.1016/j.sbspro.2010.04.039

[31] Bogusz, W., Dariusz, M., Leszek, C. and Igor, H. (2016) The Concept of the Devel-

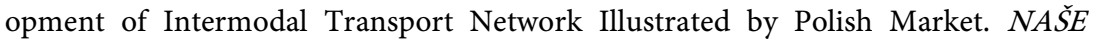
MORE: Znanstveni časopis za more i pomorstvo, 64, 33-37. https://doi.org/10.17818/NM/2017/1.6

[32] Polo, M. II (2013) Annual Work Programme. Annex 1.

[33] European Commission (2001) European Transport Policy for 2010. Time to Decide. COM 370 Final.

[34] Arnold, P., Peeters, D. and Thomas, I. (2004) Modelling a Rail/Road Intermodal Transportation System. Transportation Research Part E, 40, 255. https://doi.org/10.1016/j.tre.2003.08.005

[35] Jencek, P. and Twrdy, E. (2008) Development of Regional Transport Logistics Terminal. Transport Logistics Approach, 4, 239-249.

[36] PMAWCA (2016). http://www.agpaoc-pmawca.org

[37] Nadoun Coulibaly (2019) Togo: Faure Gnassingbé lance officiellement son PND. Economie and Finance, Politique Economique du 03 mars 2019 à 16h06, Jeune Afrique.

https://www.jeuneafrique.com/743441/economie/togo-faure-gnassingbe-lance-offici ellement-son-plan-national-de-developpement

[38] Borderless (2016) Regional Integration through the Development of Trade and Transport. Executive Secretariat, Borderless Alliance.

[39] Rajiv, D., Rabindra, N.B., Behzad, G. and Aditya, P. (2011) Optimal Pricing and Terminal Location for a Rail-Truck Intermodal Service-A Case Study. International Journal of Logistics Research and Applications, 14, 335-349. https://doi.org/10.1080/13675567.2011.643778

[40] Schrijver, A. (1998) Theory of Linear and Integer Programming. John Wiley and Sons, Hoboken. 


\section{Appendices}

Appendix 1. Preselected intermodal terminals and distance between nodes.

\begin{tabular}{|c|c|c|}
\hline Corridor Section & Nodes & Distance $(\mathrm{km})$ \\
\hline \multirow{4}{*}{$\begin{array}{l}\text { Port-Preselected } \\
\text { Terminal }\end{array}$} & Lome-Blitta (Y1) & 263 \\
\hline & Lome-Kara (Y2) & 411 \\
\hline & Lome-Mango (Y3) & 550 \\
\hline & Lome-Dapaong (Y4) & 620 \\
\hline \multirow{12}{*}{ Terminal-LLC } & Blitta-Bamako & 1710 \\
\hline & Kara-Bamako & 1562 \\
\hline & Mango-Bamako & 1423 \\
\hline & Dapaong-Bamako & 1353 \\
\hline & Blitta-Ouagadougou & 665 \\
\hline & Kara-Ouagadougou & 517 \\
\hline & Mango-Ouagadougou & 378 \\
\hline & Dapaong-Ouagadougou & 308 \\
\hline & Blitta-Niamey & 959 \\
\hline & Kara-Niamey & 811 \\
\hline & Mango-Niamey & 672 \\
\hline & Dapaong-Niamey & 602 \\
\hline
\end{tabular}

Source: Adapted from Google map.

Appendix 2. Average transport cost per mode.

\begin{tabular}{ccc}
\hline Country & $\begin{array}{c}\text { Transport cost-road } \\
\text { (USD/ton/km) }\end{array}$ & $\begin{array}{c}\text { Transport cost-rail } \\
\text { (USD/ton/km) }\end{array}$ \\
\hline Cote d'Ivoire & 0.17 & 0.14 \\
Benin & 0.18 & $\mathrm{n} / \mathrm{a}$ \\
Nigeria & 0.2 & $\mathrm{n} / \mathrm{a}$ \\
Togo & 0.16 & 0.14 \\
Ghana & 0.14 & $\mathrm{n} / \mathrm{a}$ \\
\hline
\end{tabular}

Source: Adapted from Borderless (2016). 